Article

\title{
Improving the Treatment Performance of Low Impact Development Practices-Comparison of Sand and Bioretention Soil Mixtures Using Column Experiments
}

\author{
Abtin Shahrokh Hamedani ${ }^{1, *(D)}$, Arianne Bazilio ${ }^{2}$, Hanieh Soleimanifar ${ }^{3}$, Heather Shipley ${ }^{1}$ and \\ Marcio Giacomoni ${ }^{1}$ (D) \\ 1 Department of Civil and Environmental Engineering, University of Texas at San Antonio, One UTSA Circle, \\ San Antonio, TX 78249, USA; heather.shipley@utsa.edu (H.S.); marcio.giacomoni@utsa.edu (M.G.) \\ 2 Environmental Science Program and Chemistry Department, Trinity College, 300 Summit St, Hartford, \\ CT 06106, USA; arianne.bazilio@trincoll.edu \\ 3 The Nomad Group LLC, 45 South Park Place \#4, Morristown, NJ 07960, USA; \\ Hsoleimanifar@thenomadgroup.com \\ * Correspondence: abtin.shahrokhhamedani@utsa.edu
}

Citation: Shahrokh Hamedani, A.; Bazilio, A.; Soleimanifar, H.; Shipley, H.; Giacomoni, M. Improving the Treatment Performance of Low Impact Development

Practices-Comparison of Sand and Bioretention Soil Mixtures Using Column Experiments. Water 2021, 13, 1210. https://doi.org/10.3390 /w13091210

Academic Editors: Peter Weiss and Ryan Winston

Received: 24 March 2021

Accepted: 24 April 2021

Published: 27 April 2021

Publisher's Note: MDPI stays neutral with regard to jurisdictional claims in published maps and institutional affiliations.

Copyright: (C) 2021 by the authors Licensee MDPI, Basel, Switzerland. This article is an open access article distributed under the terms and conditions of the Creative Commons Attribution (CC BY) license (https:// creativecommons.org/licenses/by/ $4.0 /)$.

Abstract: Low impact development (LID) practices, such as bioretention and sand filter basins, are stormwater control measures designed to mitigate the adverse impacts of urbanization on stormwater. LID treatment performance is highly dependent on the media characteristics. The literature suggests that bioretention media often leach nutrients in the stormwater effluent. The objective of this study was to analyze the treatment performance of different sand and bioretention soil mixtures. Specifically, this investigation aimed to answer whether the use of limestone and recycled glass could improve the treatment performance of bioretention systems. Column experiments were designed to assess (1) the removal efficiencies of different sand and bioretention soil mixtures and (2) the impact of plant uptake on removal rates. Enhanced pollutant removal was observed for the custom blends with addition of limestone sand, indicating mean dissolved and total phosphorus removal of $44.5 \%$ and $32.6 \%$ respectively, while the conventional bioretention soil mixtures leached phosphorus. Moreover, improved treatment of dissolved and total copper was achieved with mean removal rates of $70.7 \%$ and $93.4 \%$, respectively. The results suggest that the nutrient effluent concentration decreased with the addition of plants, with mean phosphorus removal of $72.4 \%$, and mean nitrogen removal of $22 \%$ for the limestone blend.

Keywords: stormwater control measure (CSM); bioretention; limestone sand; pollutant removal; nutrients; stormwater quality; column experiment; pilot study

\section{Introduction}

Low impact development (LID) practices or green infrastructure (GI) are strategies used to mitigate the adverse impacts of urbanization on the hydrologic regime and the environment by restoring the natural hydrologic flow [1]. LID practices control stormwater quantity by mimicking the natural flow, and enhance stormwater quality through natural physical, chemical, and biological treatment processes [1,2]. The treatment performance of LID practices is dependent on the design components such as media composition and local conditions such as climate, leading to variable performances. The literature indicates that some LID practices fail to remove some pollutants: for instance, several studies show leaching of nutrients such as phosphorus and nitrogen species [3-7].

Two of the most commonly used LID stormwater control measures-especially in arid and semi-arid regions-are bioretention and sand filter basins. Studies have shown that sand filter basins perform well in reducing the peak flow and runoff volume as well as removing particulate pollutant. However, they are not effective in the removal of dissolved 
pollutants $[3,8,9]$. On the other hand, bioretention systems have the potential to improve the removal of dissolved pollutants because of the chemical and biological processes that occur within the soil media and plants, including adsorption, biotransformation, bioaccumulation, and bio-uptake [1,10-12]. One limitation of bioretention systems is the high nutrient content of the bioretention soil mixtures that can lead to high effluent nutrient concentration, and subsequently eutrophication [4]. Furthermore, bioretention systems might retain the antibiotic-resistant bacterial communities in the stormwater, leading to contaminated soil and plants that can later be transmitted to humans [13].

Numerous studies have investigated impacts of soil media, soil amendments, and vegetation on the performance of bioretention systems. Hsieh and Davis [14] examined the impact of media characteristics on removal efficiencies by conducting field and pilot tests. The authors observed consistent removal rates for oil/grease and heavy metals, while nutrient removal rates were inconsistent both in the bioretention columns and on-site facilities. Nutrient removal was impacted by the runoff flow path through the media and the contact time, whereas the removal of heavy metals was directly linked to the adsorption capacity of the soil media [10,14-16]. More than $90 \%$ of the heavy metals were captured by the bioretention media, while the role of plants was found to be less significant [17]. Barrett et al. [18] observed greater pollutant removal efficiencies for bioretention soil mixtures compared to the sand filter medium. The results of this laboratory column study showed nutrient export of as much as twice the influent concentration for the bioretention soil mixtures alone, while a significant nutrient removal enhancement was achieved after the addition of plants. Therefore, vegetation was identified as the key component of the bioretention systems for the effective removal of nutrients [18-20]. Studies have also reported enhanced and consistent pollutant removal by the use of engineered soil mixtures with added soil amendments such as biochar and spent lime in the bioretention systems [21-26].

Although bioretention systems and sand filters have shown improved stormwater quality, they are still not widely applied, mainly due to the perceived high capital and operation costs. Therefore, the use of abundant or recycled materials can be very beneficial. One of the alternative and inexpensive materials that has been used in wastewater treatment filtration systems is crushed recycled glass [27-30]. Horan and Lowe [29] found that use of recycled glass as a tertiary filter medium reduces media usage by $10 \%$, and treats $10 \%$ more flow with up to $70 \%$ TSS removal. Elliot [28] recommended recycled glass as a substitute for sand because of its satisfactory filtration performance, lower cost, and durability that makes it more economical. Barrett et al. [18] and Limouzin et al. [20] have suggested the use of limestone gravel in the submerged zone of the bioretention systems for the further removal of phosphorus. Limestone is a natural mineral composed of calcites-principally calcium and magnesium carbonates $\left(\mathrm{CaCO}_{3}, \mathrm{MgCO}_{3}\right)$-resulting in high adsorption capacity. Previous studies have found limestone effective in the removal of phosphorus through the adsorption and formation of hydroxyapatite $\left(\mathrm{Ca}_{5}\left(\mathrm{PO}_{4}\right)_{3} \mathrm{OH}\right)[31,32]$, and heavy metals through adsorption and precipitation processes [32-34]. At low concentrations, metals adsorb to the calcite surface via exchange, while at high concentrations, the precipitation of metal oxides and metal carbonates is the dominant removal process [34]. Limestone is also widely available and is relatively inexpensive worldwide, since about $10 \%$ of the earth's land surface is covered with limestone deposits [32].

The objective of this study was to analyze and compare the treatment performance of different sand and bioretention soil mixtures enriched with alternative materials. In particular, this investigation aimed to answer whether the use of manufactured sand from limestone and recycled glass could improve the treatment performance of bioretention systems. To answer this question, pilot-scale column experiments were designed to test the treatment performances of nine different soil media. The column experiments were carried out in three main phases. The objectives of the first phase were to compare sand to the commonly used standard bioretention soil mixture and also to introduce potential native and abundant media that could reduce the cost and enhance the pollutant removal 
efficiencies. Initial results suggested improved removal efficiencies for the limestone sand, as the native and abundant media. In the second phase, a new bioretention soil mixture was manufactured by substituting regular sand with limestone sand in the media composition. After identification of the two best performing media, the impact of vegetation on pollutant removal rate was investigated in the third phase by studying the performance of three drought-tolerant plants.

\section{Materials and Methods}

\subsection{Column and Media Specification}

The column experiments were conducted in a greenhouse environment where temperature is controlled and maintained at $30 \pm 4{ }^{\circ} \mathrm{C}$ approximately. A total of twelve columns-101.6 cm in height with $30.5 \mathrm{~cm}$ internal diameter-were built using PVC pipes (Figure 1). Each column was built with three layers following the typical design of bioretention systems specified by the San Antonio River Authority (SARA) LID Technical Design Guidance [11]. The 25.4-cm drainage layer consists of drainage stone (ASTM\#57), choking stone (ASTM\#8), and regular sand (ASTM\#9), and the 61-cm filtration layer contains the tested media.
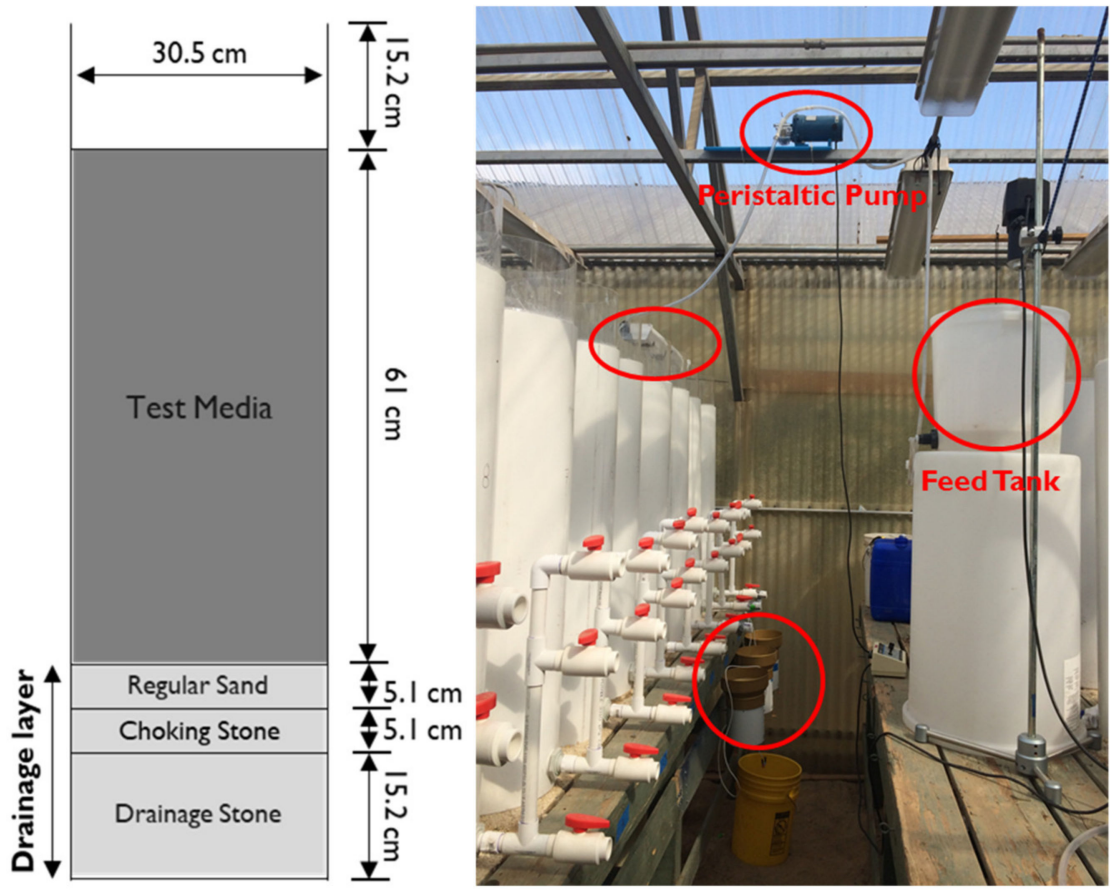

Figure 1. Profile of columns composition and injection apparatus including feed tank, agitator, peristaltic pump, and distributing gutter; and rain gauges to record outflow.

A total of nine different soil media were tested in phases one and two, including (1) Regular Sand: silica-based sand that is typically used in sand filter basins; (2) Limestone Sand (Man.Sand): manufactured sand from crushed limestone; (3) Biofilter532: sandy loam commonly used in bioretention areas manufactured with regular sand, fines, and biosolids as organic matter; (4) Recycled Glass+Biofilter532 (R.G. + Biofilter): blend composed of half recycled glass and half Biofilter532; (5) Lime-Mix: mixture of limestone sand and clay-loam (25\% crushed limestone sand, $70 \%$ clay-loam, and $5 \%$ of hardwood mulch); (6) Blend\#1: blend of limestone sand, fines, and organic matter (hardwood mulch); (7) Blend\#2: the iron-amended version of Blend\#1; (8) Biofilter433: an alternated version of Biofilter532 containing green waste (combination of leaves and hardwood mulch) as organic matter, instead of biosolids; and (9) Biofilter433MS: similar in composition to the Biofilter433 with the use of limestone sand instead of regular sand. 
Prior to running the column tests, sieve analysis (ASTM standard method C33/C33M [35] and C136/C136M [36]), hydraulic conductivity, and porosity tests (ASTM standard methods F1815 [37] and C20 [38]) were performed to determine the size distribution and permeability of each media, respectively. The Synthetic Precipitation Leaching Procedure (SPLP) test (SW-846 Test Method 1312) was performed to determine the pollutant content of the soil media prior to the column tests.

\subsubsection{Column Experiments-Phase I}

Media 1-4 were tested in the first phase of the study. Sand and Biofilter532 were tested to compare the performance of sand filters versus bioretention media. Additionally, two alternative media including crushed recycled glass and limestone sand were selected with the purpose of (1) water quality performance enhancement and (2) cost reduction.

\subsubsection{Column Experiments-Phase II}

A limestone-based bioretention soil mixture (Lime-Mix) was manufactured in the concrete laboratory of University of Texas at San Antonio (UTSA) following the standard bioretention soil mixture specifications [11]. Due to reproducibility limitations of the Lime-Mix in large volumes, local material supplier companies were contacted to produce customized mixtures using limestone sand (Blend\#1, Blend\#2, and Blend433MS). Accordingly, the second phase of the column test was performed by testing media 5-9 on the list.

\subsubsection{Column Experiments-Phase III}

After identifying the top two performing soil media, the columns were emptied, cleaned, and filled with the two top performing media (6 columns of each). Three native plants_Pink Muhly (Muhlenbergia capillaris), Inland Sea Oats (Chasmanthium latifolium), and Frogfruit (Phyla nodiflora) - were added to the columns to determine if and to what extent plant uptake may assist in the removal of pollutants.

\subsection{Synthetic Stormwater}

The synthetic stormwater was generated using deionized (DI) water and chemical salts (Table 1) to achieve the targeted pollutant concentration adopted from regional stormwater studies [39]. To best represent the real stormwater, solids $(<150 \mu \mathrm{m})$ in the synthetic stormwater were collected from accumulated sediments in one of the UTSA sand filter basins' pre-treatment chamber, which drains 6.5 ha (16 acres) including a parking lot, two avenues, and a natural area. $\mathrm{A} \mathrm{pH}$ of 7.4 was used for the synthetic stormwater in accordance to the previous stormwater data at the UTSA main campus [9], using a $0.5 \mathrm{M}$ carbonate buffer and adjusting with sodium hydroxide $(\mathrm{NaOH})$ or hydrochloric acid $(\mathrm{HCl})$ as needed. 
Table 1. Targeted concentration ( $\mathrm{mg} / \mathrm{L}$ ) of pollutants, required volume of stock solution for 5 gallons DI water, and the chemicals used in manufacturing the stock solution.

\begin{tabular}{|c|c|c|c|}
\hline Pollutant & Target Concentration $C_{\text {in }}^{\text {Target }}(\mathrm{mg} / \mathrm{L})$ & Stock Solution (mL) & Chemicals (Salts) \\
\hline TSS & 100 & - & Solids $(<150 \mu \mathrm{m})$ \\
\hline Nitrate $\left(\mathrm{NO}_{\mathrm{X}}\right)$ as $\mathrm{N}$ & 0.3 & 1.89 & Potassium nitrate $\left(\mathrm{KNO}_{3}\right)$ \\
\hline $\begin{array}{l}\text { Total Kjeldhal Nitrogen } \\
(\mathrm{TKN})\left(\text { Org } \mathrm{N}+\mathrm{NH}_{3}-\mathrm{N}\right)\end{array}$ & $1.85(0.85+1.0)$ & 189.27 & $\begin{array}{c}\text { Nicotinic acid }\left(\mathrm{C}_{6} \mathrm{H}_{5} \mathrm{NO}_{2}\right)+ \\
\text { Ammonium chloride }\left(\mathrm{NH}_{4} \mathrm{Cl}\right)\end{array}$ \\
\hline Total Phosphorus (TP) & 0.2 & 1.89 & $\begin{array}{c}\text { Mono-potassium phosphate } \\
\left(\mathrm{KH}_{2} \mathrm{PO}_{4}\right)\end{array}$ \\
\hline Total Copper $(\mathrm{TCu})$ & 0.02 & 1.89 & Copper (II) sulfate $\left(\mathrm{CuSO}_{4}\right)$ \\
\hline Total Zinc (TZn) & 0.13 & 1.89 & Zinc chloride $\left(\mathrm{ZnCl}_{2}\right)$ \\
\hline Total Lead (TPb) & 0.08 & 18.93 & Lead nitrate $\left(\mathrm{PbNO}_{3}\right)$ \\
\hline Buffer $(\mathrm{M})$ & $0.05 \mathrm{M}$ & 0.189 & $\begin{array}{l}\text { Sodium carbonate anhydrous } \\
\qquad\left(\mathrm{Na}_{2} \mathrm{CO}_{3}\right)\end{array}$ \\
\hline
\end{tabular}

The pumping apparatus consisted of a $30.2 \mathrm{~L}$ (8-gallons) feed tank, agitator engine and propeller (Arrow Engineering \#2000), peristaltic pump (Cole-Parmer Cat\# 7567-70) with $10 \mathrm{~mm}(3 / 8 \mathrm{in})$ tubing, and distributing gutters. The synthetic stormwater was constantly mixed by the propeller in the feed tank to maintain homogeneity and was delivered to the columns by the peristaltic pump. A distributing gutter with two orifices was used to inject two columns of same media simultaneously. The water level in the gutter and the orifices' flowrate were monitored throughout the experiment to maintain consistency, and the feed tank was refilled to sustain the desired injection rate and total volume of $150 \mathrm{~mL} / \mathrm{min}$ and $\approx 38 \mathrm{~L}$ (10 gallons), respectively. Column runs were performed once for each column, and in triplicates (three identical columns of each media) for the first phase and duplicates (two identical columns of each media) for the second phase for each media type. Two influent samples $(300 \mathrm{~mL})$ and ten time-based effluent samples $(300 \mathrm{~mL})$ were collected. After collecting the initial effluent sample, samples were taken every $15 \mathrm{~min}$ for the first hour and every $30 \mathrm{~min}$ for the remaining time. A total of 12 samples per column were collected and stored at $4{ }^{\circ} \mathrm{C}$.

\subsection{Water Quality Analysis}

The collected influent and effluent samples were tested for the following water quality parameters: Total Suspended Solids (TSS) [mg/L]; Orthophosphate (P) and Total Phosphorus (TP) [mg/L as $\left.\mathrm{PO}_{4}{ }^{3-}-\mathrm{P}\right]$; Nitrate (N) and Total Nitrogen (TN) $\left[\mathrm{mg} / \mathrm{L}\right.$ as $\left.\mathrm{NO}_{3}{ }^{-}-\mathrm{N}\right]$; Dissolved and Total concentrations of heavy metals including Copper, Zinc and Lead $[\mu \mathrm{g} / \mathrm{L}]$. The sample preparation, storage, and analysis complied with the Standard Methods for the Examination of Water and Wastewater [40]. The instruments and methods used for water quality analyses are listed in Table S1 (Supplementary Materials). The mean influent and effluent concentrations were used to calculate the removal rate:

$$
R R(\%)=\frac{\bar{C}_{\text {in }}-\bar{C}_{\text {out }}}{\bar{C}_{\text {in }}} \times 100
$$

where $\bar{C}_{\text {in }}$ and $\bar{C}_{\text {out }}$ are the mean influent and effluent concentrations of a particular pollutant.

The flow weighted mean concentration (FWMC) is a measure of total pollutant load per total discharge. To calculate the FWMC, the following formula was applied for each soil media-pollutant pair.

$$
F W M C=\frac{\sum_{1}^{n}\left(C_{i} t_{i} q_{i}\right)}{\sum_{1}^{n}\left(t_{i} q_{i}\right)}
$$

where $C_{i}$ is the concentration of a specific pollutant in the $i$ th sample, $t_{i}$ is the time for the $i$ th sample, $q_{i}$ is the flowrate for the $i$ th sample, and $n$ is the number of samples. 


\subsection{Statistical Analysis}

To examine the removal efficiencies of each type of media and to determine whether the mean influent and effluent concentrations were statistically different, $t$-tests and nonparametric Wilcoxon tests were performed at a confidence level of $95 \%(p<0.05)$, for normal and non-normal distributions, respectively. The Shapiro-Wilk test was performed to determine the normality of the dataset. The F-test was performed to test the variances and to determine the type of $t$-test for each dataset (Bartlett F-test for normal and Levene's F-test for non-normal distribution). The significance of differences between mean effluent concentrations was also examined at the same confidence level $(p<0.05)$.

\section{Results and Discussion}

\subsection{Media Physical and Chemical Properties}

The sieve analysis results identified the recycled glass blend (R.G. + Biofilter) with the coarsest particle size distribution, whereas Biofilter433 had the highest percentage of fine media $(72.3 \%)$, resulting in slower water movement and the lowest hydraulic conductivity of $19 \mathrm{~mm} / \mathrm{h}$ (Table 2). The recommended bioretention soil media specification requires an infiltration rate of $12.7-152.4 \mathrm{~mm} / \mathrm{h}$ [11]. The requirements for size distribution are $85-88 \%$ sand passing through the $1 / 4$ in sieve $(6.35 \mathrm{~mm}), 8-12 \%$ fines passing through \#270 sieve $(0.053 \mathrm{~mm})$, and $2-5 \%$ of organic matter [11]. All of the bioretention soil media met the infiltration rate criteria except for Biofilter433MS and R.G. + Biofilter with hydraulic conductivities of 344 and $616 \mathrm{~mm} / \mathrm{h}$, respectively. As for the chemical composition, SPLP results (Table 2) indicated the highest nutrient content in Biofilter 532 and Biofilter- 433 and $433 \mathrm{MS}$, as well as higher copper content compared to the other soil media.

\subsection{Water Quality Analysis}

\subsubsection{Column Experiments-Phase I}

The results indicate high TSS removal rates ranging from $84.6 \%(p=0.0003)$ to $91.6 \%$ $(p=0.005)$ for Biofilter532, Sand and Man.Sand, respectively (Table 3). High variations in the influent TSS concentration and consequent inconsistencies in the influent pollutant load were observed (Figures 2 and 3, Table S2), which was caused by the partial accumulation of sediments inside the distributing gutter as well as the natural difference in the matrix of solids that were used in the preparation of each batch of the synthetic stormwater. The large variations between the median (central line) and mean influent concentrations (green circle) in the boxplots (Figure 3) indicate the influent inconsistencies. 
Table 2. Physical and chemical properties of the soil media.

\begin{tabular}{|c|c|c|c|c|c|c|c|c|c|c|c|}
\hline \multirow{2}{*}{$\begin{array}{c}\text { Media } \\
\text { [(No\#) Name] }\end{array}$} & \multicolumn{2}{|c|}{ Size Distribution ${ }^{a}$} & \multirow{2}{*}{$\begin{array}{c}\text { Organic Matter } \\
(\%)\end{array}$} & \multirow{2}{*}{$\begin{array}{c}\begin{array}{c}\text { Hydraulic } \\
\text { Conductivity }\end{array} \\
\mathrm{mm} / \mathrm{h}\end{array}$} & \multirow{2}{*}{$\begin{array}{c}\text { Permeability } \\
\mathrm{mm}^{2}\end{array}$} & \multirow[t]{2}{*}{$\mathrm{pH}$} & \multirow{2}{*}{$\begin{array}{c}\begin{array}{c}\text { Total } \\
\mathbf{P}\end{array} \\
\mathrm{mg} / \mathrm{kg} \\
\end{array}$} & \multirow{2}{*}{$\begin{array}{c}\text { Total N } \\
\mathrm{mg} / \mathrm{kg}\end{array}$} & \multirow{2}{*}{$\begin{array}{c}\text { Total Cu } \\
\mu \mathrm{g} / \mathrm{kg}\end{array}$} & \multirow{2}{*}{$\begin{array}{c}\text { Total Pb } \\
\mu \mathrm{g} / \mathrm{kg}\end{array}$} & \multirow{2}{*}{$\begin{array}{r}\text { Total Zn } \\
\mu \mathrm{g} / \mathrm{kg}\end{array}$} \\
\hline & 270 & $1 / 4$ & & & & & & & & & \\
\hline (1) Regular Sand & 0 & 100 & 0 & 375 & $1.0 \times 10^{-4}$ & 7.7 & 0.8 & 14.4 & 42.0 & 30.8 & 581 \\
\hline (2) Man.Sand & 0 & 100 & 0 & 1096 & $3.0 \times 10^{-4}$ & 9.0 & 2.6 & 11.4 & 44.8 & 16.4 & 401 \\
\hline (3) Biofilter532 & 23.9 & 100 & 5.8 & 61 & $1.6 \times 10^{-5}$ & 8.3 & 56.6 & 59.4 & 299 & 23.2 & 745 \\
\hline (4) R.G. + Biofilter & 1 & 96 & 2.9 & 616 & $1.7 \times 10^{-4}$ & 8.3 & 35.4 & 27 & 187 & 14.4 & 466 \\
\hline (5) Lime-Mix & 22.0 & 100 & 5.0 & 61 & $1.6 \times 10^{-5}$ & 9.4 & 9.8 & 43.4 & 117 & 7.8 & 419 \\
\hline (6) Blend\#1 & 38.0 & 100 & 1.4 & 35 & $9.2 \times 10^{-6}$ & 8.9 & 6.8 & 29 & 57.6 & 10.4 & 458 \\
\hline (7) Blend\#2 & 38.0 & 100 & 1.4 & 34 & $9.0 \times 10^{-6}$ & - & - & - & - & - & - \\
\hline (8) Biofilter433 & 72.3 & 100 & 3.9 & 19 & $5.1 \times 10^{-6}$ & 8.4 & 23.1 & 81.6 & 190 & 21.4 & 602 \\
\hline (9) Biofilter433MS & 30.9 & 100 & 3.7 & 344 & $8.9 \times 10^{-5}$ & 8.6 & 23.6 & 88.8 & 160 & 17.6 & 382 \\
\hline
\end{tabular}

a (\%) passing through sieve 1/4in $(6.35 \mathrm{~mm})$ and \#270 $(0.053 \mathrm{~mm}) —$ Not measured, should be same as Blend\#1.

Table 3. Removal efficiencies (\%) of the pollutants—phase I and phase II.

\begin{tabular}{|c|c|c|c|c|c|c|c|c|c|}
\hline \multirow{2}{*}{ Water Quality Parameter } & \multicolumn{9}{|c|}{ Removal Efficiency (\%) } \\
\hline & Sand & Man.Sand & Biofilter 532 & R.G. + Biofilter & Lime-Mix & Blend\#1 & Blend\#2 & Biofilter 433MS & Biofilter 433 \\
\hline TSS & 91.6 & 91.6 & 84.6 & 85.2 & 94.9 & 87.3 & 86.0 & 75.7 & 86.6 \\
\hline Orthophosphate & 49.8 & 93.1 & - & -22.7 & 77.4 & -32.9 & 89.1 & -583 & -266 \\
\hline Total Phosphorus & 46.1 & 70.3 & -80.8 & -69.4 & 53.2 & -20.5 & 65.2 & -380 & -178 \\
\hline Nitrate & -108 & -35.4 & - & - & 4.0 & -7.2 & -3.7 & -12.7 & 59.3 \\
\hline Total Nitrogen & -6.25 & -32.9 & 12.3 & -22.2 & 29.7 & -11.8 & 1.0 & -11.3 & 13.3 \\
\hline Dissolved Lead & 98.9 & 99.9 & 100 & 77.4 & 95.9 & 100 & 100 & 95.0 & 99.8 \\
\hline Total Lead & 99.1 & 99.8 & 99.3 & 96.5 & - & 100 & 100 & 99.4 & 98.5 \\
\hline Total Copper & 69.5 & 93.8 & -102 & 29.1 & 69.2 & 63.6 & 79.2 & 64.4 & 75.9 \\
\hline Dissolved Zinc & 93.2 & 95.9 & 64.9 & 90.2 & 89.7 & 92.1 & 98.3 & 93.8 & 87.0 \\
\hline Total Zinc $(\mu \mathrm{g} / \mathrm{L})$ & 89.0 & 87.9 & 85.7 & 88.5 & - & 94.6 & 87.8 & 91.7 & 96.2 \\
\hline
\end{tabular}

- Missing values are due to technical issues with colorimetric methods and ICP-MS. 

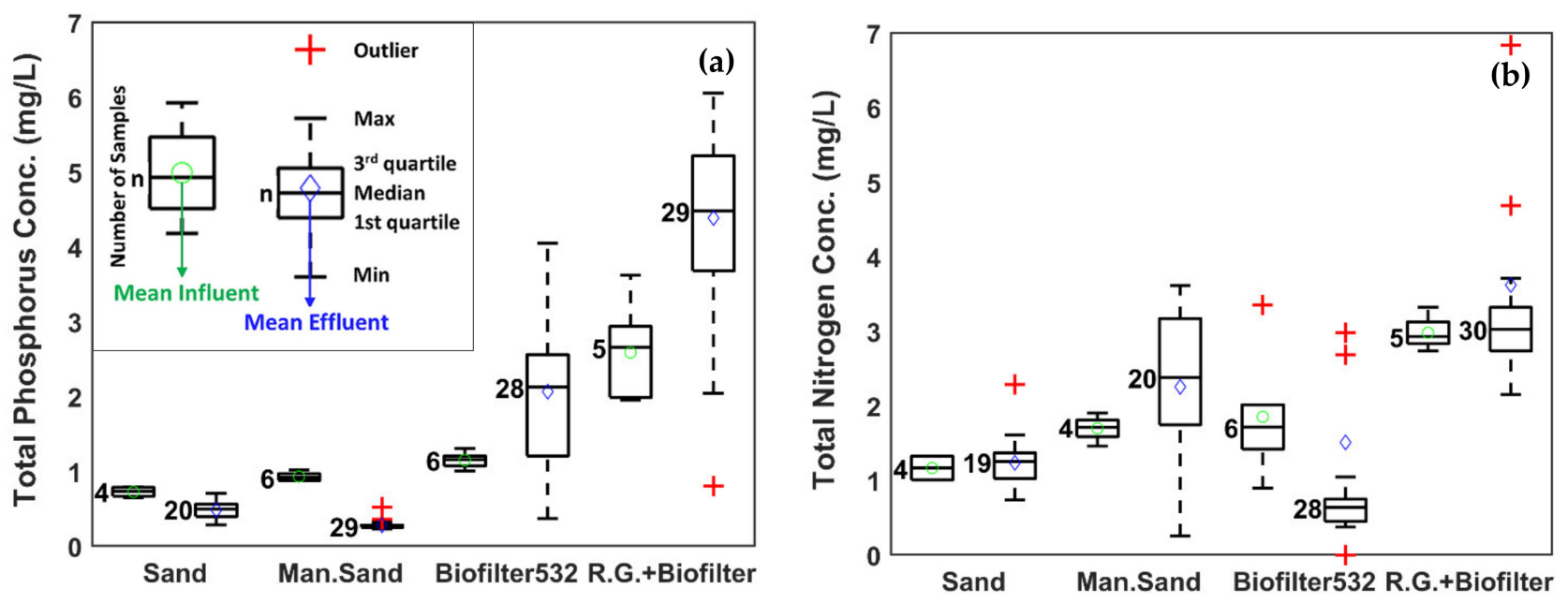

Figure 2. Paired boxplots of influent and effluent concentration (mg/L) for (a) TP and (b) TN. The boxplots represent the median (central line), first and third quartile (box), minimum and maximum concentrations (whiskers), outliers (red plus), mean influent (green circle), and mean effluent concentration (blue diamond), and $\mathrm{n}$ is the number of samples.

Studies have shown that the high removal of TSS through sedimentation and filtration correlates to the high removal of particulate contaminants, namely, the heavy metals that are bound to the sediments $[10,15]$, which agrees with the column test results (Figure 3, Table 3). On the other hand, the removal of the dissolved metals occurs through biological and chemical mechanisms and is highly dependent on the adsorption capacity of the soil media $[10,15,16]$. The results indicate high total lead and zinc removal efficiencies averaging $98.6 \%$ and $87.8 \%$, respectively. On the contrary, a significant difference is observed in the copper removal rates and effluent concentrations $(p<0.0001)$ (Tables 3 and 4$)$ with the highest total copper FWMC values of 51.54 and $43.9 \mu \mathrm{g} / \mathrm{L}$ for Biofilter532 and R.G. + Biofilter, respectively ( $p=0.0002, p=0.34$ ) (Figure $3 a)$. The leaching of copper by bioretention media has been reported by previous studies [7,39], indicating that the association of copper with organic matter leads to the desorption of copper in the effluent (Table 2). Since higher organic matter is correlated with higher phosphorus content and export, copper and phosphorus concentration are intercorrelated [7,41]. Similar to the total copper measurements, poor dissolved copper removal was observed (Table 3). Biofilter532 had the highest dissolved copper effluent concentration-in accordance with its high copper content (Table 2)—with significant difference from the influent $(p=0.02)$, whereas Sand and R.G. + Biofilter showed no significant difference $(p=0.16$ and 0.43). Man.Sand showed superior treatment performance for all dissolved heavy metals compared to that of the Sand, which showed limitations and only removed $20.3 \%$ and $75.2 \%$ of the dissolved copper and zinc $(p<0.0001, p=0.0003)$, respectively (Table 3$)$.

The Man.Sand performed best in removing dissolved and total heavy metals with significantly lower effluent concentrations for all measured elements $(p<0.03)$, whereas the use of recycled glass in the R.G. + Biofilter did not show significant improvements in the pollutant removal efficiencies. Thus, limestone sand was selected as the substitute media to generate the enhanced bioretention soil mixture. 

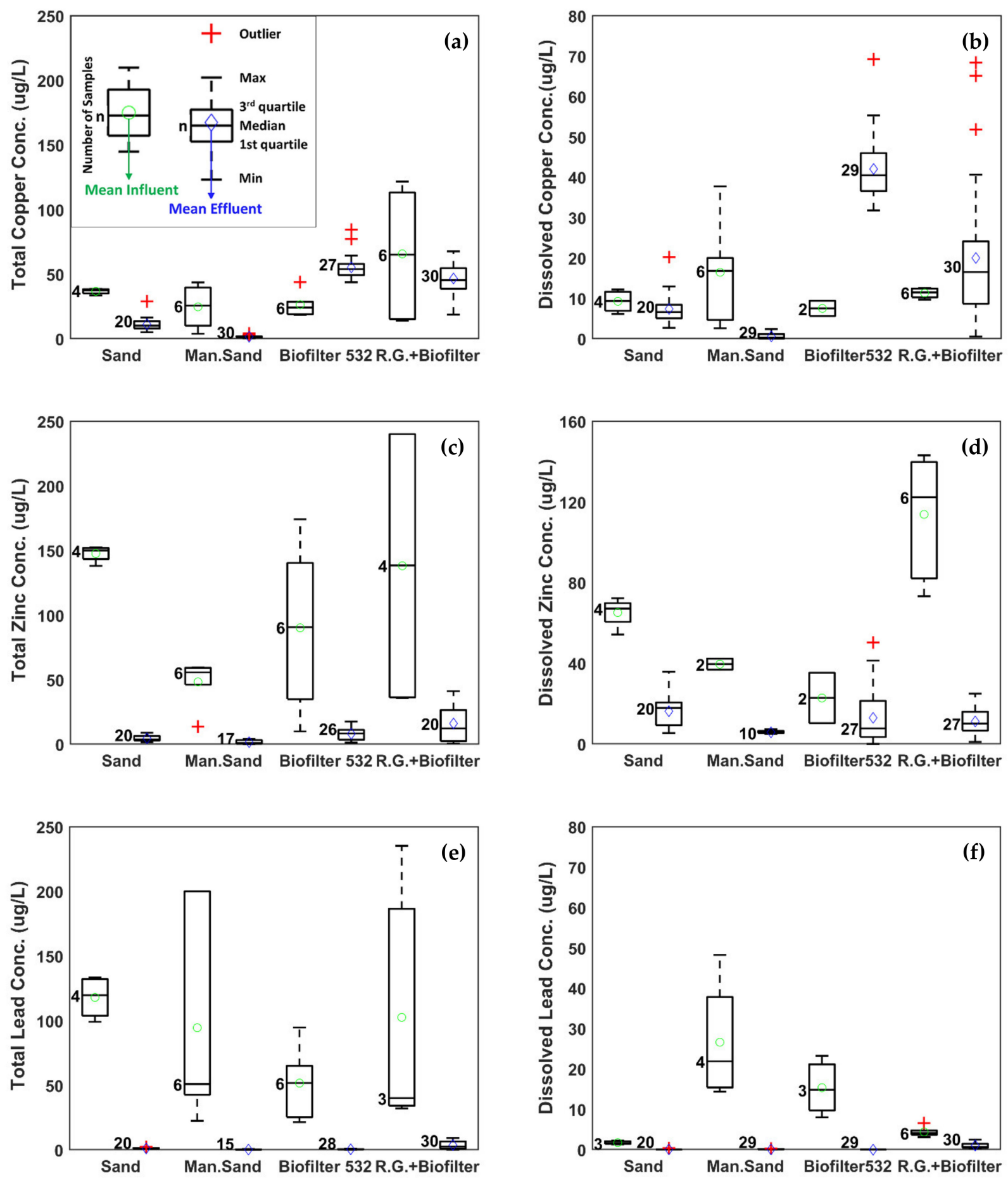

Figure 3. Paired boxplots of influent and effluent concentration $(\mu \mathrm{g} / \mathrm{L})$ for total and dissolved heavy metals including $(\mathbf{a}, \mathbf{b})$ Copper, (c,d) Zinc, and (e,f) Lead. 
Table 4. Effluent flow weighted mean concentration (FWMC) values for each media-pollutant pair-phase I and phase II.

\begin{tabular}{|c|c|c|c|c|c|c|c|c|c|}
\hline \multirow{2}{*}{ Water Quality Parameter } & \multicolumn{9}{|c|}{ Flow Weighted Mean Concentration (FWMC) } \\
\hline & Sand & Man.Sand & Biofilter 532 & R.G. + Biofilter & Lime-Mix & Blend\#1 & Blend\#2 & Biofilter 433MS & Biofilter 433 \\
\hline TSS (mg/L) & 2.22 & 2.19 & 12.06 & 8.87 & 2.15 & 14.2 & 7.47 & 21.6 & 13.3 \\
\hline Orthophosphate (mg/L P) & 0.09 & 0.01 & - & 0.86 & 0.03 & 0.14 & 0.02 & 1.03 & 0.64 \\
\hline Total Phosphorus (mg/L P) & 0.53 & 0.32 & 1.38 & 5.05 & 0.33 & 0.65 & 0.28 & 3.41 & 2.21 \\
\hline Nitrate $(\mathrm{mg} / \mathrm{L} \mathrm{N})$ & 2.24 & 0.86 & - & - & 0.41 & 0.55 & 0.69 & 0.89 & 0.30 \\
\hline Total Nitrogen (mg/L N) & 1.01 & 1.86 & 0.87 & 3.32 & 1.47 & 1.95 & 1.67 & 1.35 & 1.45 \\
\hline Dissolved Lead ( $\mu \mathrm{g} / \mathrm{L})$ & 0.36 & 0.08 & 0 & 1.14 & 0 & 0 & 0 & 2.50 & 0.14 \\
\hline Total Lead $(\mu \mathrm{g} / \mathrm{L})$ & 1.12 & 0.13 & 0.41 & 4.17 & - & 0 & 0 & 2.01 & 1.44 \\
\hline Dissolved Copper $(\mu \mathrm{g} / \mathrm{L})$ & 5.93 & 0.62 & 41.5 & 19.6 & 6.94 & 9.82 & 7.41 & 15.6 & 9.28 \\
\hline Total Copper $(\mu \mathrm{g} / \mathrm{L})$ & 9.47 & 1.19 & 51.5 & 43.9 & 4.46 & 12.6 & 7.46 & 19.4 & 24.8 \\
\hline Dissolved Zinc $(\mu \mathrm{g} / \mathrm{L})$ & 4.37 & 0.49 & 8.76 & 12.1 & 20.3 & 10.3 & 1.25 & 9.88 & 6.89 \\
\hline Total Zinc $(\mu \mathrm{g} / \mathrm{L})$ & 15.8 & 5.74 & 15.0 & 14.5 & - & 21.7 & 29.8 & 26.9 & 12.3 \\
\hline
\end{tabular}

- Sufficient data was not available. 


\subsubsection{Column Experiments-Phase II}

Phase II of the experiments tested five bioretention soil mixtures including four limestone blends and one standard bioretention soil mixture (Table S3). The TSS measurements of the tested media in phase II agreed with those of phase I, indicating overall high removal efficiency $(\approx 90 \%)$ (Table 3$)$.

As for nutrient treatment, the four customized limestone mixtures showed considerable improvement in the treatment of TP and relatively smaller effluent TP FWMC values, except for the Biofilter433MS (Table 4 and Table S3). The Lime-Mix and Blend\#2 had the highest TP removal efficiencies of $53.2 \%$ and $65.2 \%$, respectively $(p=0.0001, p=0.002)$, while Blend\#1 showed relatively similar influent and effluent concentrations $(p=0.13)$ with leaching of $20.5 \%$ (Table 3). The Biofilter 433 showed slightly reduced effluent TP concentration compared to the Biofilter532 $(p=0.46)$, indicating that substituting green-waste for biosolids was effective, as it led to smaller organic matter and phosphorus content of $3.9 \%$ and $23 \mathrm{mg} / \mathrm{kg}$, respectively (Table 2). Although the effluent TP concentration is smaller for Bifilter433, a lower removal rate is achieved, which is due to the smaller influent concentration compared to the Biofilter532 (Table 3 and Table S2). Moreover, larger boxplots and longer whiskers for the Biofilter433MS, Biofilter433, and Biofilter532 indicate greater discrepancies in the effluent concentrations over time, while the limestone mixtures showed more consistent results (Figure 4). No significant difference was evident between the influent and effluent TN concentrations for all limestone mixtures (Figure $4 \mathrm{~b})(p=0.1$, $0.39,0.91,0.29)$, with some removal for Lime-Mix and Blend\#2 (29.7\% and $1 \%$, respectively). The Biofilter433-similar to Biofilter532-removed $13.3 \%$ of TN $(p=0.0008)$ and $59.3 \%$ of $\mathrm{N}(p=0.003)$ likely due to its slower infiltration rate (Table 2$)$, which provides the required saturated zone for denitrification processes.
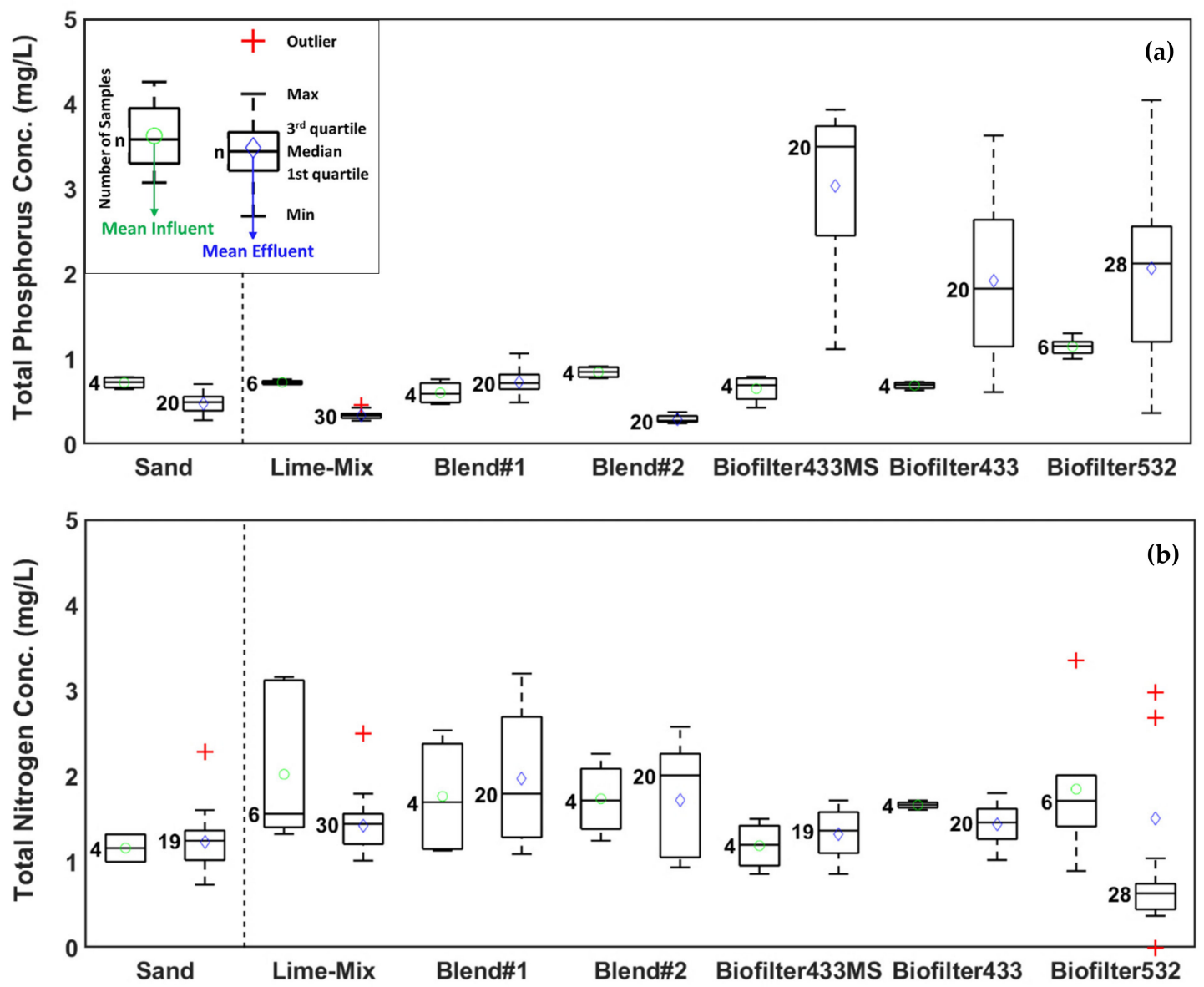

Figure 4. Paired boxplots of influent and effluent concentration for (a) TP and (b) TN (mg/L) comparing sand to the standard and customized bioretention soil mixtures (phases I and II). 
The total metals influent and effluent concentrations were significantly different with high removal efficiencies of $99 \%, 93 \%$, and $68 \%$ on average for lead, zinc, and copper (Figure 5), whereas relatively higher dissolved effluent copper concentrations were observed (Figure 5a). However, the limestone mixtures showed reduced values compared to the tested media in phase I $(p<0.0001)$, which is indeed correlated with the phosphorus removal and media copper content (Tables 2 and 3). High effluent total zinc concentration of FWMC (Table 4) was likely due to the solids from the media that contain mean total zinc content of $506 \mu \mathrm{g} / \mathrm{kg}$ (Table 2). Blend\#1 and Biofilter433 were selected as the two top performing media for phase III, since (1) Lime-Mix is not reproducible in large quantities and (2) potential impacts of additive iron (Blend\#2) were not studied leaving Blend\#1 and Biofilter433 as the best bioretention soil mixtures for the next phase.
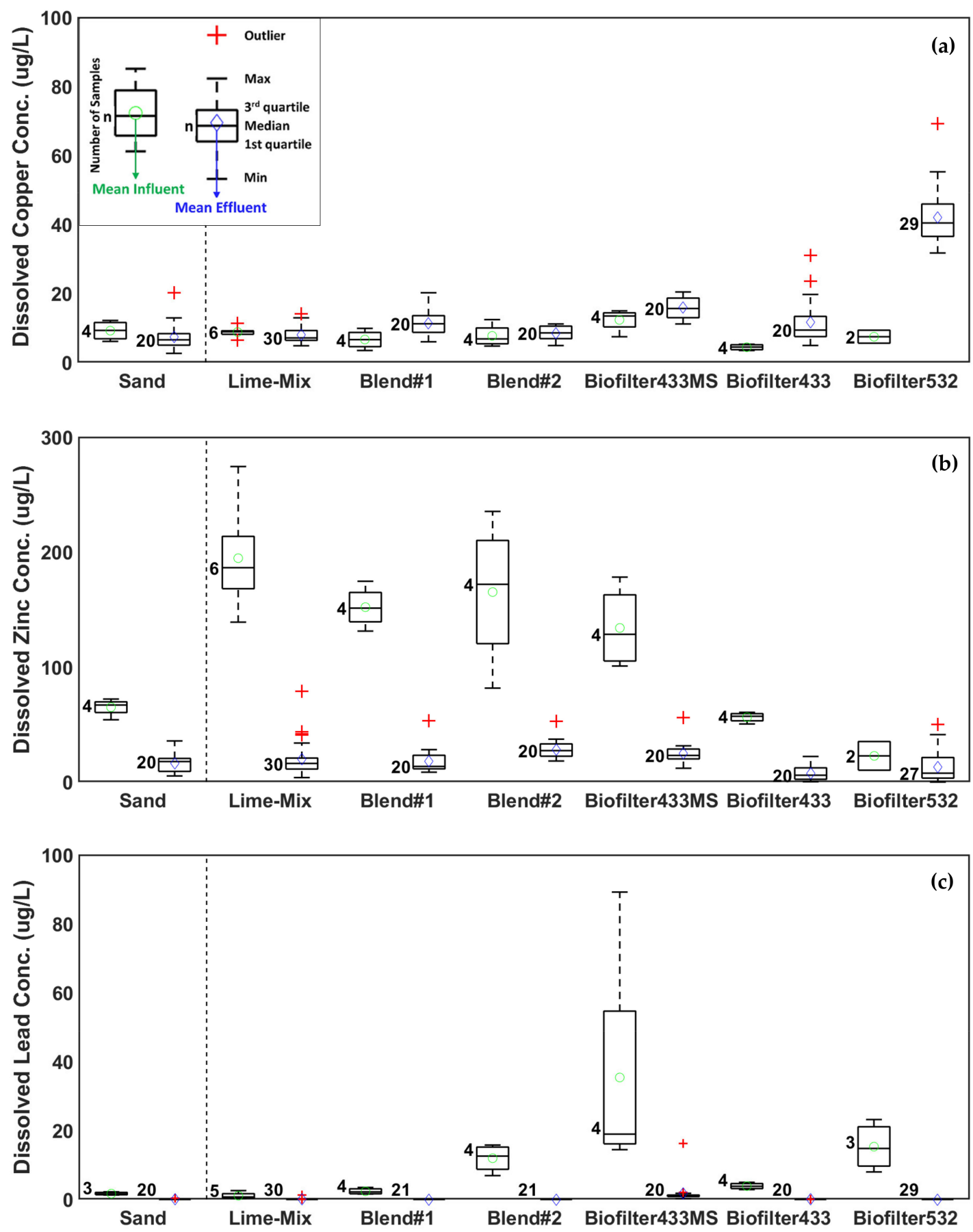

Figure 5. Paired boxplots of influent and effluent concentration for dissolved metals ( $\mu \mathrm{g} / \mathrm{L})$ (a) Copper, (b) Zinc, and (c) Lead, comparing sand to the standard and customized bioretention soil mixtures. 


\subsubsection{Column Experiments-Phase III}

The treatment performance of vegetated Blend\#1 and Biofilter 433 columns was tested to assess the impact of plant uptake on removal efficiencies and to determine whether different plant species impact treatment performances differently. The results (Table S4 and Table 5) showed increased solids (TSS) in all effluent samples compared to phase II $(p<0.0001)$. The mean TSS removal rate was reduced from $88 \%$ to $32 \%$ and $30 \%$ for Blend\#1 and Biofilter433, respectively. This might be due to the added mulch layers at the top of the columns and the conveyance of solids through plant root canals within the media. Wang et al. [7] also found non-vegetated bioretention cells more effective in the removal of TSS. The Sea Oats columns had lower effluent TSS concentrations (55\% removal rate) compared to Frogfruit (35\% and 20\%) and Muhly (6\% and 16\%) for Belnd\#1 and Biofilter433, respectively $(p<0.0001, p=0.019)$ (Table 5).

Table 5. Removal efficiencies (\%) of the pollutants before and after the addition of plants—phase III.

\begin{tabular}{|c|c|c|c|c|c|c|c|c|}
\hline \multirow{4}{*}{ Water Quality Parameter } & \multicolumn{8}{|c|}{ Removal Efficiency (\%) } \\
\hline & \multicolumn{6}{|c|}{ Phase III with Plants } & \multirow{2}{*}{\multicolumn{2}{|c|}{$\begin{array}{c}\text { Phase II } \\
\text { No Plants }\end{array}$}} \\
\hline & \multicolumn{3}{|c|}{ Blend\#1 } & \multicolumn{3}{|c|}{ Biofilter433 } & & \\
\hline & Sea Oats & Frogfruit & Muhly & Sea Oats & Frogfruit & Muhly & Blend\#1 & Biofilter433 \\
\hline TSS & 55.2 & 34.6 & 6.0 & 55.0 & 19.9 & 15.6 & 87.3 & 86.6 \\
\hline Orthophosphate & 87.9 & 82.8 & 80.8 & -275 & -420 & -355 & -32.9 & -266 \\
\hline Total Phosphorus & 64.7 & 59.0 & 59.2 & -202 & -289 & -255 & -20.5 & -179 \\
\hline Nitrate & 46.1 & 55.7 & 35.0 & 72.9 & 64.3 & 65.6 & -7.2 & 59.3 \\
\hline Total Nitrogen & 5.5 & -2.9 & -7.3 & -0.4 & -10.6 & -4.7 & -11.8 & 13.3 \\
\hline Dissolved Lead & 84.3 & 100 & 98.5 & 71.3 & 100 & 68.5 & 100 & 99.8 \\
\hline Total Lead & 98.2 & 97.9 & 98.8 & 99.2 & 97.7 & 97.7 & 100 & 98.5 \\
\hline Dissolved Copper & 44.0 & 64.6 & 63.8 & -17.8 & -169 & -39.1 & -71.5 & -162 \\
\hline Total Copper & 47.4 & 77.0 & 73.2 & 68.5 & 73.4 & 71.1 & 63.6 & 75.9 \\
\hline Dissolved Zinc & 86.8 & 96.3 & 94.7 & 88.7 & 89.8 & 91.5 & 92.1 & 87.0 \\
\hline Total Zinc & 95.7 & 95.6 & 90.1 & 93.9 & 86.0 & 87.9 & 94.6 & 96.2 \\
\hline
\end{tabular}

On the other hand, significant improvement in the nutrient removal was observed, especially for Blend\#1 (Figure 6). The mean effluent concentrations indicated decreased phosphorus content to $0.03-0.04(\mathrm{mg} / \mathrm{L})$ and $0.3-0.35(\mathrm{mg} / \mathrm{L})$ for orthophosphate $(p<0.0001)$ and total phosphorus $(p=0.001)$ of Blend\#1 after the addition of plants, respectively. No significant difference was observed between performances of different plants in the removal of total phosphorus ( $p=0.095)$, whereas Muhly effluents had slightly higher orthophosphate concentration $(p<0.0001)$. Conversely, an increased effluent phosphorus concentration with no significant difference between plants was observed for Biofilter433 ( $p=0.59, p=0.35$ for $\mathrm{P}$ and TP respectively). The nitrogen measurements (Figure $6 \mathrm{~b}$ ) suggested that plant uptake enhanced nitrate removal to $35-56 \%$ and $64-73 \%$ for Blend\#1 and Biofilter433, respectively (Table 5). Similar to phosphorus results, the impact of plants on nitrate removal was more significant in Blend\#1 $(p<0.0001)$ compared to Biofilter 433 ( $p=0.36$ ). The mean nitrate removal rate was increased to $46 \%$ for vegetated columns from $-7.2 \%$ (leaching) for Blend\#1 in the second phase of the experiment, whereas Biofilter433 showed only up to $13.6 \%$ enhancement with no significant difference in performance $(p=0.24)$. There was no significant improvement in total nitrogen removal, and slight leaching was evident (Figure 6c), which might be associated with the increased washed off solids in the effluent samples. Slightly greater total nitrogen removal of Sea Oat columns was in accordance with the greater TSS removal rate as well (Table 5). 

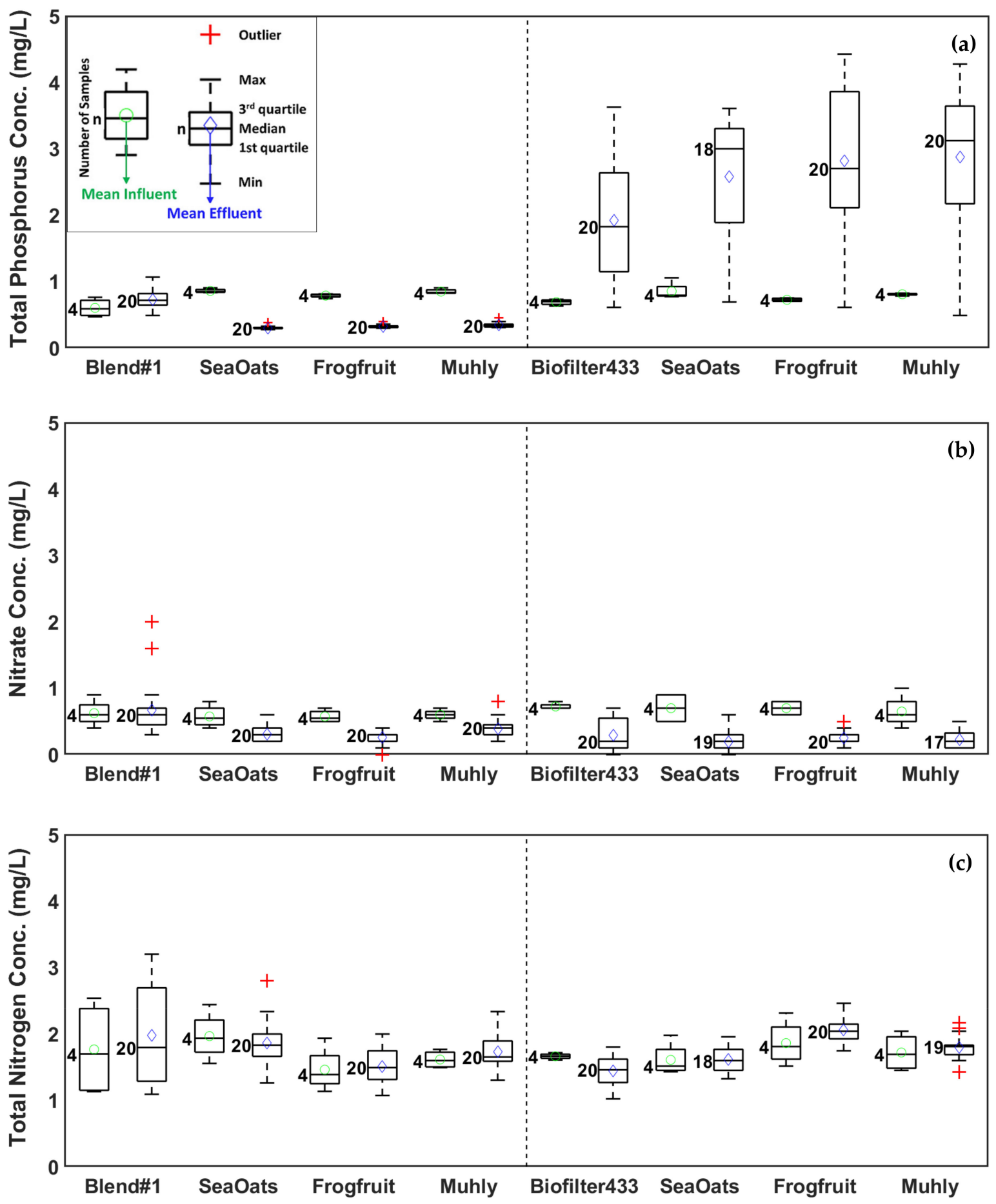

Figure 6. Paired boxplots of influent and effluent concentration (mg/L) for (a) TP, (b) N, and (c) TN, comparing phase II: non-vegetated bioretention columns (Blend\#1 and Biofilter433), and phase III: vegetated bioretention columns (SeaOats, Frogfruit and Muhly).

The concentration of heavy metals and the corresponding removal rates indicated no significant difference before and after the addition of plants, except for copper. The dissolved copper removal was enhanced significantly $(p<0.0001)(-71 \%$ to $57 \%)$-in correlation with the enhanced phosphorus removal rate-whereas total copper effluent concentrations were similar $(p=0.06)$. Due to increased concentration of solids in the effluent, slightly lower overall total metals removal was observed. 
When comparing the water quality parameters and removal efficiencies between phases II and III, it can be inferred that plants enhanced the removal of nutrients, particularly for Blend\#1 (Figure 6). The mean orthophosphate removal was increased to $83.8 \%$ from $-32.9 \%(p<0.0001)$, while the mean total phosphorus removal rate was increased to $61.0 \%$ from $-29.7 \%(p=0.001)$ (Table 5). Enhanced nitrate removal was achieved for both media in phase III (Figure 6c), with overall increase of $52.8 \%$ and $8.3 \%$ for Blend\#1 and Biofilter433, respectively $(p<0.0001$ and $p=0.36)$. The heavy metal removal efficiencies were relatively similar for all columns with the exception of dissolved copper with an overall enhanced removal of $129 \%$ and $87 \%$ for Blend\#1 and BioFilter433 $(p<0.0001$ and $p=0.31$ ), respectively (Table 5). The impact of increased solids in the effluent samples of the vegetated columns and reduced TSS removal requires further investigations. Overall, the results confirmed that vegetation enhances some pollutant removal (nutrients and dissolved copper) in bioretention systems.

\section{Conclusions}

A series of column experiments were performed to assess treatment efficiencies of nine different media. All media demonstrated good filtration capacity and high TSS removal $(\approx 90 \%)$, which also translated into a high removal of particulate contaminants. The removal of dissolved pollutants is highly dependent on the adsorption capacity of the soil media and infiltration rate. For that reason, limestone sand showed the best treatment performance (orthophosphate and dissolved heavy metals, particularly) due to its high adsorption capacity, whereas the use of recycled glass in the bioretention mixture did not provide any significant improvements. Accordingly, limestone sand was used as a substitute of regular sand in the bioretention soil mixtures, and as expected, enhanced removal efficiencies were achieved compared to the standard bioretention soil mixtures and sand. Excess nutrient content was a major observed disadvantage of bioretention soil mixtures, resulting in greater effluent nutrient concentrations (phosphorus) than the influent. This issue was addressed by adding vegetation in the third phase of the column tests, where significant improvement in the removal of dissolved nutrients was achieved, indicating the positive effect of plant uptake on the pollutant removal in the bioretention systems.

In this study, we used accumulated solids in a sand filter basin's inlet chamber as TSS in the synthetic stormwater, to better represent actual stormwater of urban areas. However, this approach led to inconsistent influent pollutant concentration among all different media batches, and it can be highlighted as a weakness in our methodological approach. On the other hand, solids influents differences were not significant to impair our major findings and the conclusions of this experimental study. Further research is required on the plant-soil interactions to better understand the role of plants in pollutant removal and find the potential causes of the increased effluent TSS and poor treatment of Biofilter433 even after the addition of plants. Moreover, the clogging of LID systems causes a major limitation on their hydrologic and treatment performance that needs to be prevented for a reliable effective operation in the long term. A future study is underway where the two bioretention systems alongside sand are tested in a full-scale LID testbed. The monitoring of the LID testbed will provide us with a better understanding on the long-term performance of a regular bioretention, a limestone-based bioretention, and a sand filter basin operating under the same conditions on the field scale.

Supplementary Materials: The following are available online at https: / www.mdpi.com/article / 10.3390/w13091210/s1, Table S1. Water quality parameters (pollutants), units, methods, instrumentation, and detection limits; Table S2. Mean influent and effluent concentration \pm standard deviation of measured water quality parameters-Phase I; Table S3. Mean influent and effluent concentration \pm standard deviation of measured water quality parameters-Phase II; and Table S4. Mean effluent concentration \pm standard deviation of water quality parameters-Phase III. 
Author Contributions: Conceptualization, H.S. (Heather Shipley) and M.G.; Data curation, A.S.H. and A.B.; Formal analysis, A.S.H. and H.S. (Hanieh Soleimanifar); Funding acquisition, H.S. (Heather Shipley) and M.G.; Investigation, A.S.H., A.B. and H.S. (Hanieh Soleimanifar); Methodology, A.B., H.S. (Hanieh Soleimanifar), H.S. (Heather Shipley) and M.G.; Project administration, M.G.; Software, A.S.H. and H.S. (Hanieh Soleimanifar); Supervision, H.S. (Heather Shipley) and M.G.; Validation, A.B. and M.G.; Visualization, A.S.H.; Writing—original draft, A.S.H.; Writing—review and editing, A.S.H., A.B., H.S. (Heather Shipley) and M.G. All authors have read and agreed to the published version of the manuscript.

Funding: This research was funded by the City of San Antonio (COSA) and San Antonio River Authority (SARA).

Institutional Review Board Statement: Not applicable.

Informed Consent Statement: Not applicable.

Data Availability Statement: The following data are available from the corresponding author by request: Tables and figures within the text and Supplementary Materials, containing the experimental data, MATLAB code for generating the boxplots, statistical analysis results on JMP Pro 14 software.

Acknowledgments: The authors express their appreciation to the City of San Antonio (COSA) and San Antonio River Authority (SARA) for funding this project and also the staff for their assistance and guidance. We thank Fernando Dornelles (UFRGS, Brazil) for his helpful comments on the manuscript. We also express gratitude for Urban Soil LLC and New Earth Compost for donating the soil media.

Conflicts of Interest: The authors declare no conflict of interest. The funders had no role in the design of the study; in the collection, analyses, or interpretation of data; in the writing of the manuscript, or in the decision to publish the results.

\section{References}

1. US EPA. Reducing Stormwater Costs through Low Impact Development (LID) Strategies and Practices; United States Environmental Protection Agency, Nonpoint Source Control Branch (4503T): Washington, DC, USA, 2007; p. 37.

2. Prince George's County. Low Impact Development Design Strategies an Integrated Design Approach; Prince George's County, Maryland, Department of Environmental Resource, Programs and Planning Division: Largo, MD, USA, 1999.

3. Barrett, M.E. Performance, Cost, and Maintenance Requirements of Austin Sand Filters. J. Water Resour. Plan. Manag. 2003, 129, 234-242. [CrossRef]

4. Barrett, M.E. Complying with the Edwards Aquifer Rules; Texas Commission on Environmental Quality (TCEQ): Austin, TX, USA, 2005; p. 415.

5. Ahiablame, L.M.; Engel, B.A.; Chaubey, I. Effectiveness of Low Impact Development Practices: Literature Review and Suggestions for Future Research. Water Air Soil Pollut. 2012, 223, 4253-4273. [CrossRef]

6. Eckart, K.; McPhee, Z.; Bolisetti, T. Performance and implementation of low impact development-A review. Sci. Total Environ. 2017, 607-608, 413-432. [CrossRef]

7. Wang, R.; Zhang, X.; Li, M.-H. Predicting bioretention pollutant removal efficiency with design features: A data-driven approach J. Environ. Manag. 2019, 242, 403-414. [CrossRef] [PubMed]

8. Shahrokh Hamedani, A.S.; Bazilio, A.; Cerda, C.; Manjarres, A.; Hall, A.; Shipley, H.; Giacomoni, M. Assessing the Performance of Bioretention and Sand Filter Media Using Columns and Synthetic Stormwater. In Proceedings of the World Environmental and Water Resources Congress 2019: Water, Wastewater, and Stormwater, Urban Water Resources, and Municipal Water Infrastructure, Pittsburgh, PA, USA, 19-23 May 2019; p. 14.

9. Zarezadeh, V.; Lung, T.; Dorman, T.; Shipley, H.J.; Giacomoni, M. Assessing the performance of sand filter basins in treating urban stormwater runoff. Environ. Monit. Assess. 2018, 190, 697. [CrossRef] [PubMed]

10. Davis, A.P.; Traver, R.G.; Hunt, W.F. Improving Urban Stormwater Quality: Applying Fundamental Principles. J. Contemp. Water Res. Educ. 2010, 146, 3-10. [CrossRef]

11. Dorman, T.; Ferry, M.; Wright, J.; Wardynski, B.; Smith, J.; Tucker, B.; Riverson, J.; Teague, A.; Bishop, K. San Antonio River Basin Low Impact Development Technical Guidance Manual; San Antonio River Authority: San Antonio, TX, USA, 2013.

12. Hsieh, C.-H.; Davis, A. Multiple-event study of bioretention for treatment of urban storm water runoff. Water Sci. Technol. 2005, 51, 177-181. [CrossRef]

13. Scaccia, N.; Vaz-Moreira, I.; Manaia, C.M. Persistence of wastewater antibiotic resistant bacteria and their genes in human fecal material. FEMS Microbiol. Ecol. 2020, 96, 96. [CrossRef] [PubMed]

14. Hsieh, C.-H.; Davis, A.P. Evaluation and Optimization of Bioretention Media for Treatment of Urban Storm Water Runoff. J. Environ. Eng. 2005, 131, 1521-1531. [CrossRef]

15. Baum, P.; Kuch, B.; Dittmer, U. Adsorption of Metals to Particles in Urban Stormwater Runoff-Does Size Really Matter? Water 2021, 13, 309. [CrossRef] 
16. Blecken, G.-T.; Zinger, Y.; Deletić, A.; Fletcher, T.D.; Viklander, M. Impact of a submerged zone and a carbon source on heavy metal removal in stormwater biofilters. Ecol. Eng. 2009, 35, 769-778. [CrossRef]

17. Sun, X.; Davis, A.P. Heavy metal fates in laboratory bioretention systems. Chemosphere 2007, 66, 1601-1609. [CrossRef]

18. Barrett, M.E.; Limouzin, M.; Lawler, D.F. Effects of Media and Plant Selection on Biofiltration Performance. J. Environ. Eng. 2013, 139, 462-470. [CrossRef]

19. DelVecchio, T.; Welker, A.; Wadzuk, B.M.; Dunn, C.N.; Van Weele, B. Field and Laboratory Studies of Nutrient Removal in Different Soil Types for Vegetated Stormwater Control Measures. In Proceedings of the World Environmental and Water Resources Congress 2017, Sacramento, CA, USA, 21-25 May 2017; pp. 345-356.

20. Limouzin, M.; Lawler, D.F.; Barrett, M.E. Performance Comparison of Stormwater Biofiltration Designs; Center for Research in Water Resources, University of Texas at Austin: Austin, TX, USA, 2011.

21. Guo, H.; Lim, F.; Zhang, Y.; Lee, L.; Hu, J.; Ong, S.; Yau, W.; Ong, G. Soil column studies on the performance evaluation of engineered soil mixes for bioretention systems. Desalination Water Treat. 2014, 54, 3661-3667. [CrossRef]

22. Shrestha, P.; Salzl, M.T.; Jimenez, I.J.; Pradhan, N.; Hay, M.; Wallace, H.R.; Abrahamson, J.N.; Small, G.E. Efficacy of Spent Lime as a Soil Amendment for Nutrient Retention in Bioretention Green Stormwater Infrastructure. Water 2019, 11, 1575. [CrossRef]

23. Tian, J.; Jin, J.; Chiu, P.C.; Cha, D.K.; Guo, M.; Imhoff, P.T. A pilot-scale, bi-layer bioretention system with biochar and zero-valent iron for enhanced nitrate removal from stormwater. Water Res. 2019, 148, 378-387. [CrossRef]

24. Ulrich, B.A.; Loehnert, M.; Higgins, C.P. Improved contaminant removal in vegetated stormwater biofilters amended with biochar. Environ. Sci. Water Res. Technol. 2017, 3, 726-734. [CrossRef]

25. Wan, Z.; Li, T.; Shi, Z. A layered bioretention system for inhibiting nitrate and organic matters leaching. Ecol. Eng. 2017, 107, 233-238. [CrossRef]

26. Yang, F.; Fu, D.; Liu, S.; Zevenbergen, C.; Singh, R.P. Hydrologic and Pollutant Removal Performance of Media Layers in Bioretention. Water 2020, 12, 921. [CrossRef]

27. CWC. Evaluation of Crushed Recycled Glass as a Filtration Medium in Slow Sand Filtration; Recycling Technology Assistance Partnership (ReTAP) A program of the Clean Washington Center (CWC), a division of the Pacific Northwest Economic Region; Gray \& Osborne, Inc.: Seattle, WA, USA, 1995; p. 42.

28. Elliot, R.W. Evaluation of the use of crushed recycled glass as a filter medium. Water Eng. Manag. 2001, 148, 17-20.

29. Horan, N.; Lowe, M. Full-scale trials of recycled glass as tertiary filter medium for wastewater treatment. Water Res. 2007, 41, 253-259. [CrossRef] [PubMed]

30. Rutledge, S.O.; Gagnon, G.A. Comparing crushed recycled glass to silica sand for dual media filtration. J. Environ. Eng. Sci. 2002, 1, 349-358. [CrossRef]

31. Mateus, D.M.; Vaz, M.M.; Pinho, H.J. Fragmented limestone wastes as a constructed wetland substrate for phosphorus removal. Ecol. Eng. 2012, 41, 65-69. [CrossRef]

32. Oates, J.A.H. Lime and Limestone: Chemistry and Technology, Production and Uses; Wiley-VCH: Weinheim, Germany, 1998; ISBN 978-3-527-29527-2.

33. Aziz, H.; Othman, N.; Yusuff, M.; Basri, D.; Ashaari, F.; Adlan, M.; Othman, F.; Johari, M.; Perwira, M. Removal of copper from water using limestone filtration technique: Determination of mechanism of removal. Environ. Int. 2001, 26, 395-399. [CrossRef]

34. Aziz, H.A.; Adlan, M.N.; Ariffin, K.S. Heavy metals (Cd, Pb, Zn, Ni, Cu and Cr(III)) removal from water in Malaysia: Post treatment by high quality limestone. Bioresour. Technol. 2008, 99, 1578-1583. [CrossRef] [PubMed]

35. ASTM C33/C33M-18 Standard Specification for Concrete Aggregates; ASTM International: West Conshohocken, PA, USA, 2018.

36. ASTM C136/C136M-14 Test Method for Sieve Analysis of Fine and Coarse Aggregates; ASTM International: West Conshohocken, PA, USA, 2014.

37. ASTM F1815-11 Test Methods for Saturated Hydraulic Conductivity, Water Retention, Porosity, and Bulk Density of Athletic Field Rootzones; ASTM International: West Conshohocken, PA, USA, 2011.

38. ASTM C20-00(2015) Test Methods for Apparent Porosity, Water Absorption, Apparent Specific Gravity, and Bulk Density of Burned Refractory Brick and Shapes by Boiling Water; STM International: West Conshohocken, PA, USA, 2015.

39. Li, M.-H.; Sung, C.Y.; Kim, M.H. Bioretention for Stormwater Quality Improvement in Texas: Pilot Experiments; Texas Transportation Institute, The Texas A\&M University System: College Station, TX, USA, 2010; p. 56.

40. APHA; AWWA; WEF. Standard Methods for the Examination of Water and Wastewater, 22nd ed.; Rice, E.W., Baird, R.B., Eaton, A.D., Clesceri, L.S., Eds.; American Public Health Association: Washington, DC, USA, 2012; ISBN 978-0-87553-013-0.

41. Li, H.; Davis, A.P. Urban Particle Capture in Bioretention Media. II: Theory and Model Development. J. Environ. Eng. 2008, 134, 419-432. [CrossRef] 